\title{
Trans-Pacific dust events observed at Whistler, British Columbia during INTEX-B
}

\author{
I. G. McKendry ${ }^{1}$, A. M. Macdonald ${ }^{2}$, W. R. Leaitch ${ }^{2}$, A. van Donkelaar ${ }^{3}$, Q. Zhang ${ }^{4}$, T. Duck ${ }^{3}$, and R. V. Martin ${ }^{3}$ \\ ${ }^{1}$ Department of Geography, The University of British Columbia, Vancouver, B.C., V6T 1Z2, Canada \\ ${ }^{2}$ Science and Technology Branch, Environment Canada, Toronto, Ontario, M3H 5T4, Canada \\ ${ }^{3}$ Department of Physics and Atmospheric Science, Dalhousie University, Halifax, NS M3J 1P3, Canada \\ ${ }^{4}$ State University of New York at Albany, Albany, New York, USA
}

Received: 8 April 2008 - Published in Atmos. Chem. Phys. Discuss.: 2 June 2008

Revised: 1 September 2008 - Accepted: 15 September 2008 - Published: 30 October 2008

\begin{abstract}
The meteorology and physico-chemical characteristics of aerosol associated with two new cases of long range dust transport affecting western Canada during spring 2006 are described. Each event showed enhancements of both sulfate aerosol and crustal material of Asian origin. However, the events were of quite different character and demonstrate the highly variable nature of such events. The April event was a significant dust event with considerable enhancement of fine particle sulfate while the May event was a weaker dust event, also with significant fine particle sulfate enhancement. The latter event was notable in the sense that it was of short duration and was quickly followed by a large increase of organic material likely of regional origin. Comparison of these two events with other documented cases extending back to 1993, suggests that all dust events show coincident enhancements of sulfate and crustal aerosol. However, events vary across a wide continuum based on the magnitude of aerosol enhancements and their sulfate to calcium ratios. At one extreme, events are dominated by highly significant crustal enhancements (e.g. the well-documented 1998 and 2001 "dust" events) while at the other are events with some dust transport, but where sulfate enhancements are of very high magnitude (e.g. the 1993 event at Crater Lake and the 15 May 2006 event at Whistler). Other events represent a "mix". It is likely that this variability is a function of the comparative strengths of the dust and anthropogenic $\mathrm{SO}_{2}$ sources, the transport pathway and in particular the extent to which dust is transported across industrial $\mathrm{SO}_{2}$ sources, and finally, meteorological and chemical processes.
\end{abstract}

Correspondence to: I. G. McKendry

(ian@geog.ubc.ca)

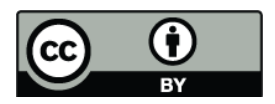

\section{Introduction}

During April-May 2006, INTEX-B (the Intercontinental Chemical Transport Experiment) was focused on the North Pacific with the goal of providing detailed chemical analysis of tropospheric air following a trans-Pacific pathway to the North American continent (e.g. Zhang et al. (2008) discuss ozone transport during INTEX-B). This intensive field campaign, involving ground based, airborne and satellite observations, was prompted by over a decade of observational and modelling studies demonstrating the relatively rapid (especially during springtime) trans-Pacific transport of both crustal material (predominately desert dusts) and anthropogenic pollutants from sources in Eurasia to North America (e.g. Jaffe et al., 1999, 2003; Husar et al., 2001; Holzer et al., 2003; Jacob et al., 1999). In this context, the mobilization and transport of mineral dust from the arid regions of the world is considered of major significance due to the role airborne crustal material plays in the global radiation balance (and hence climate forcing), cloud processes, atmospheric chemistry, oceanic and terrestrial biogeochemical processes (e.g. dust is a major source of iron and calcium), as vectors for microbes, and as a factor influencing local air quality in both "source" and "sink" regions (Prospero et al., 2002). Furthermore, recent studies suggest that dust participates in important interactions with anthropogenic pollutants such as sulfur-dioxide ( $\mathrm{SO}_{2}$ - a source of sulfate aerosol). Such pollutants are often mixed into, and interact with, the dust plumes as they pass over urban/industrial sources ( $\mathrm{Li}$ Jones and Prospero, 1998; Heald et al., 2006).

(ian@geog.ubc.ca)

Published by Copernicus Publications on behalf of the European Geosciences Union. 
Studies of trans-Pacific dust transport suggest a strong linkage between anthropogenic sulfate aerosol and crustal dust transport from Asia. For example, VanCuren's (2003) analysis of aerosol data at Crater Lake, (Oregon) and Mt. Lassen (California) shows that a mixture of dust and combustion products dominate Asian aerosol that arrives in North America. Their major constituent fractions of particles $(<2.5 \mu \mathrm{m}$ diameter) were $30 \%$ mineral, $28 \%$ organic compounds, $4 \%$ elemental carbon, $10 \%$ sulfate, $<5 \%$ nitrate, and $<1 \%$ sea salt. Heald et al. (2006), using satellite imagery, GEOS-Chem model and Interagency Monitoring for Protected Visual Environments (IMPROVE) surface network data from the western USA, have also demonstrated the strong coincidence of crustal dust and sulfate aerosol in trans-Pacific pollutant transport. Springtime Asian sulfate aerosol enhancements are shown to be greatest in Washington State and southern British Columbia with maximum 24-h enhancements reaching approximately $1.5 \mu \mathrm{g} \mathrm{m}^{-3}$ (Heald et al., 2006). These results suggest that combined dust/sulfate transport events may have important implications for the setting and attainment of visibility standards in western North America. This is particularly relevant when set against a background of burgeoning emissions of $\mathrm{SO}_{2}$ from Asia, where not only have $\mathrm{SO}_{2}$ emissions increased by $119 \%$ between 1980-2003 (Ohara et al., 2007), but also Asian sulfate influx to North America has increased 72-85\% between 1985-2006 (van Donkelaar et al., 2008). Streets and Waldhoff (2000) indicate that Asian $\mathrm{SO}_{2}$ emissions are projected to increase from $25.2 \mathrm{mt}$ in 1995 to $30.6 \mathrm{mt}$ in 2020 (assuming emission controls are implemented on large power plants) and possibly to $60.7 \mathrm{mt}$ without emission controls.

Beginning with the well-documented 1998 dust episode, a growing inventory of trans-Pacific dust events affecting North America has been established. Most of these events have involved sources in the Gobi and Takla Makan deserts Asia (Husar et al., 2001; Jaffe et al., 2003, Thulasiraman, 2002), although recently, a case of Saharan dust transport across Asia and the Pacific to North America has been documented (McKendry et al., 2007). In addition, modelling studies have identified many aspects of the climatology, interannual variability and pathways of dust transport and deposition (Holzer et al., 2003, 2005: Gong et al., 2006; Zhao et al., 2006; Chin et al., 2007). The meteorological mechanisms associated with boundary layer - free tropospheric (BL-FT) exchange of dust (and anthropogenic pollutants) have also largely been identified. BL-FT exchange processes most relevant to dust source areas include the warm conveyer belt (WCB) mechanism (Cooper et al., 2004; Stohl et al., 2002) and frontal lifting, while in receptor regions (such as western North America) subsidence, and mountain wave activity are important in bringing mid- tropospheric dust layers in range of BL entrainment processes (McKendry et al., 2001; Hacker et al., 2001).

Against this background of improved understanding of many aspects of trans-Pacific dust transport, the intensive ob- servations afforded by INTEX-B provide a further opportunity to extend the inventory of documented dust events and to examine the commonalities emerging from such a catalog of events. In this context, our goals in this paper are to:

- Describe two separate dust events identified during INTEX B

- Compare and contrast these events with previously documented cases, particularly with respect to their magnitude and chemical signature. For the latter, sulfate aerosol measurements during INTEX-B provide a rare opportunity to examine the linkage between sulfate and mineral aerosol in these cases.

\section{Methods}

\subsection{Whistler Peak}

Measurements of particles and trace gases are made by Environment Canada at a high elevation site in Whistler, BC, approximately $100 \mathrm{~km}$ north of Vancouver (Fig. 1). The site is located at the top of a ski hill, at Whistler peak, $2182 \mathrm{~m}$ (above sea level). There are no continuous combustion sources at the peak and influences from snowmobiles have been identified and removed from the data set.

At the time of INTEX-B, the ongoing measurements at Whistler Peak were $\mathrm{O}_{3}, \mathrm{CO}$, particle chemistry, particle size distributions $(0.01-20 \mu \mathrm{m})$, light scattering and light absorption. Particle chemistry consisted of 48 hour averaged filters cut at $2.5 \mu \mathrm{m}$ and analyzed by ion chromatography (IC) for ions of chloride, nitrate, sulfate, sodium, ammonium, potassium, magnesium and calcium. Particle size distributions are measured using a Scanning Mobility Particle Sizing system (SMPS) for $0.01-0.4 \mu \mathrm{m}$ diameter particles and a Grimm optical particle counter (OPC) (Model 1.108) for $0.3 \mu \mathrm{m}$ to $20 \mu \mathrm{m}$ particles. All particle sampling was through a stainless steel manifold. The manifold intake was heated to a minimum of $4^{\circ} \mathrm{C}$ in order to prevent riming of the intake when supercooled cloud was present. Temperatures were below $4^{\circ} \mathrm{C}$ about $60 \%$ of the time; the temperature record is given by Leaitch et al. (2008). In addition, the aerosol was heated by the being drawn into the room with the instruments, such that the temperature of the aerosol at the point of measurement was approximately $20^{\circ} \mathrm{C}$ and outside air temperatures ranged from about $-10^{\circ} \mathrm{C}$ to $15^{\circ} \mathrm{C}$ during the study. Details of the on-going measurements at Whistler Peak are discussed by Macdonald et al. (2008).

In addition to the $48 \mathrm{~h}$ filters, there were two other measurements of particle chemistry at Whistler Peak during INTEX-B. Size segregated particle chemistry was also measured from samples collected from about 4 p.m. one day to $10 \mathrm{a} . \mathrm{m}$. the next day using non-rotating MOUDI samplers reduced to three size cuts ( $<1 \mu \mathrm{m}, 1-3 \mu \mathrm{m}$ and $>3 \mu \mathrm{m})$. The size segregated samples were averaged only during the $18 \mathrm{~h}$ 


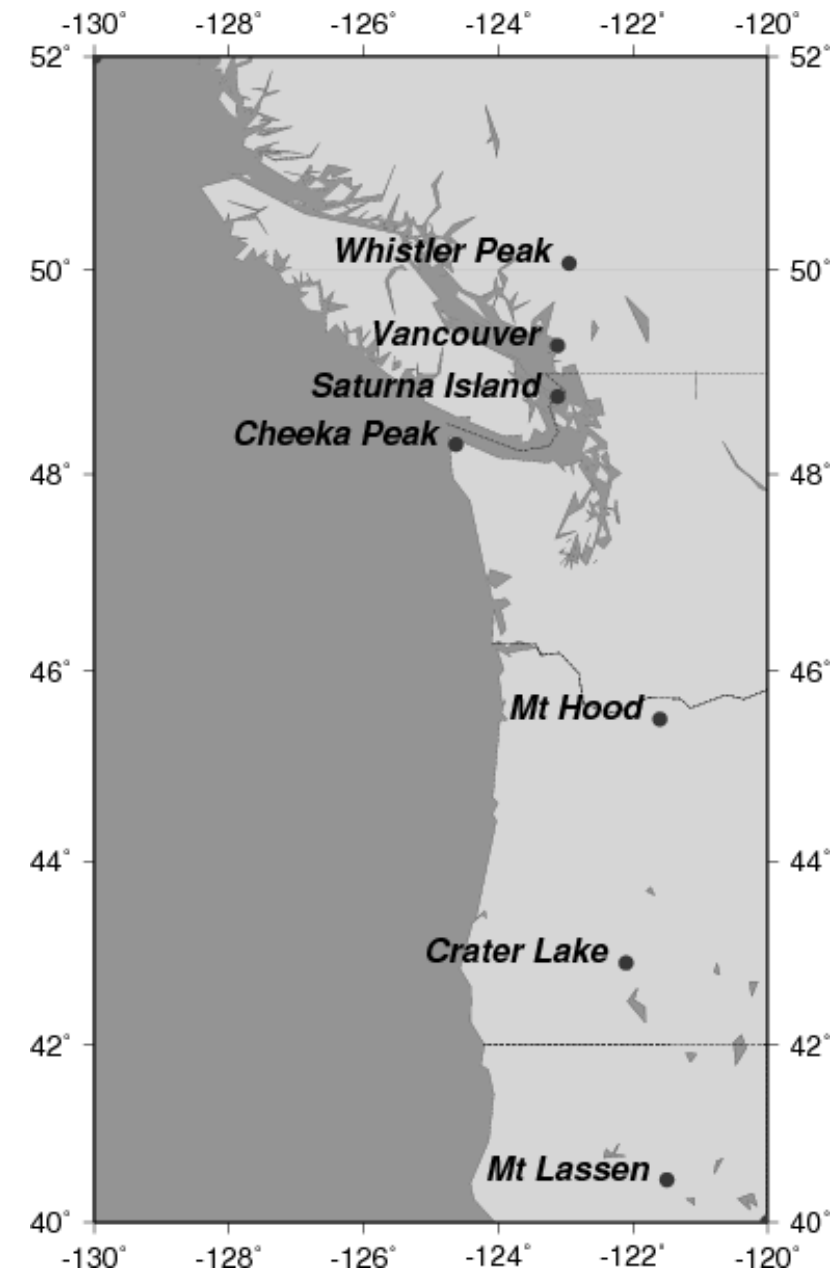

Fig. 1. Map showing study area and places mentioned in the text.

overnight period in order to reduce the influence of the daytime boundary layer on the samples. The size segregated samples were analyzed by IC for the same ions as the $48 \mathrm{~h}$ samples plus oxalate, acetate and formate. The MOUDI sampler was mounted outside so that particles entered directly into the impactor. Fine particle chemistry (fine particles defined here as $<1 \mu \mathrm{m}$ diameter) was measured using an Aerodyne High Resolution Time-of-Flight Aerosol Mass Spectrometer (HR-ToF-AMS). The observations from the HRToF-AMS are discussed by Sun et al. (2008).

\subsection{Cessna}

Measurements of $\mathrm{O}_{3}$ (TECO 49), $\mathrm{CO}$ (Aerolaser), physical and chemical size distributions of aerosol particles were conducted from a Cessna 207. The physical size distributions of the aerosol particles were measured with a Particle Measuring Systems (PMS) 7610 Condensation Particle Counter (CPC; particle number concentration >15nm), a PMS Passive Cavity Aerosol Spectrometer Probe (PCASP100X;
0.12-3 $\mu \mathrm{m})$ and a Forward Scattering Spectrometer Probe (FSSP300; 0.3-20 $\mu \mathrm{m}$ ). The CPC was mounted inboard the Cessna and the PCASP100X and FSSP300 were both mounted in pods under the wings of the aircraft. The PCASP uses an intrusive sampling system, such that the particles are at least partially dried prior to detection, whereas the FSSP uses a non-intrusive system to sample the particles (e.g. Strapp et al., 1992). The chemical size distribution was measured with an Aerodyne Quadrapole Aerosol Mass Spectrometer (Q-AMS) located inboard. The Q-AMS is used to measure mass concentrations of classes of compounds (e.g. sulfate, nitrate, ammonium and total organics). Particles between about $0.1 \mu \mathrm{m}$ and $0.7 \mu \mathrm{m}$ are efficiently transmitted into the Q-AMS (e.g. Liu et al., 2007). Fundamentals of the Q-AMS are described by Jayne et al. (2000). The aerosol was supplied to the inboard instrumentation using an open ended $0.95 \mathrm{~cm}$ OD stainless steel tube. The tube was supported outside of the aircraft and elevated about $0.5 \mathrm{~m}$ from the top of the fuselage. Ram pressure from the aircraft pushed the aerosol into and through the tubing; the end of the tubing was open to the cabin. Both the Q-AMS and CPC sampled from this inlet. Flights were approximately two hours long, and most flights consisted of ascent and descent profiles at Whistler to an altitude of about $5.3 \mathrm{~km}$. Data were recorded every second, except for the AMS data that were recorded as one-minute averages in order to try to optimize for temporal resolution and sufficient signal for detection. Further details of the instrumentation and comparisons are given by Leaitch et al. (2008).

\subsection{Modelling}

GEOS-Chem v7-04-09 at $2^{\circ} \times 2.5^{\circ}$ (www.as.harvard.edu/ chemistry/trop/geos/) was used to estimate dust emissions and transport from Asia to North America. It is driven using assimilated meteorological data from the Goddard Earth Observing System (GEOS-4) at the NASA Global Modeling Assimilation Office (GMAO). The dust module is described in detail by Fairlie et al. (2007) and includes the effects of gravitational settling as well as wet and dry deposition.

\subsection{Ancilliary data}

Crater Lake and Mount Hood are part of the Interagency Monitoring of Protected Environments (IMPROVE) network of stations (http://vista.cira.colostate.edu/improve/ Default.htm) where aerosols are collected on filters $(24 \mathrm{~h}$ samples) every third day (since 2000). Samples are analysed for elemental composition and are reported in fine $\left(\mathrm{PM}_{2.5}\right)$ and coarse $\left(\mathrm{PM}_{2.5-10}\right)$ fractions.

The Dalhousie Raman Lidar (DRL) is described by Duck et al. (2006) and was available at Whistler for the 15 May event only. It transmits an $11 \mathrm{~W}$ pulsed laser beam at $532 \mathrm{~nm}$ wavelength vertically into the atmosphere and employs a $25 \mathrm{~cm}$ diameter telescope with $1 \mathrm{mrad}$ field-of-view in the 

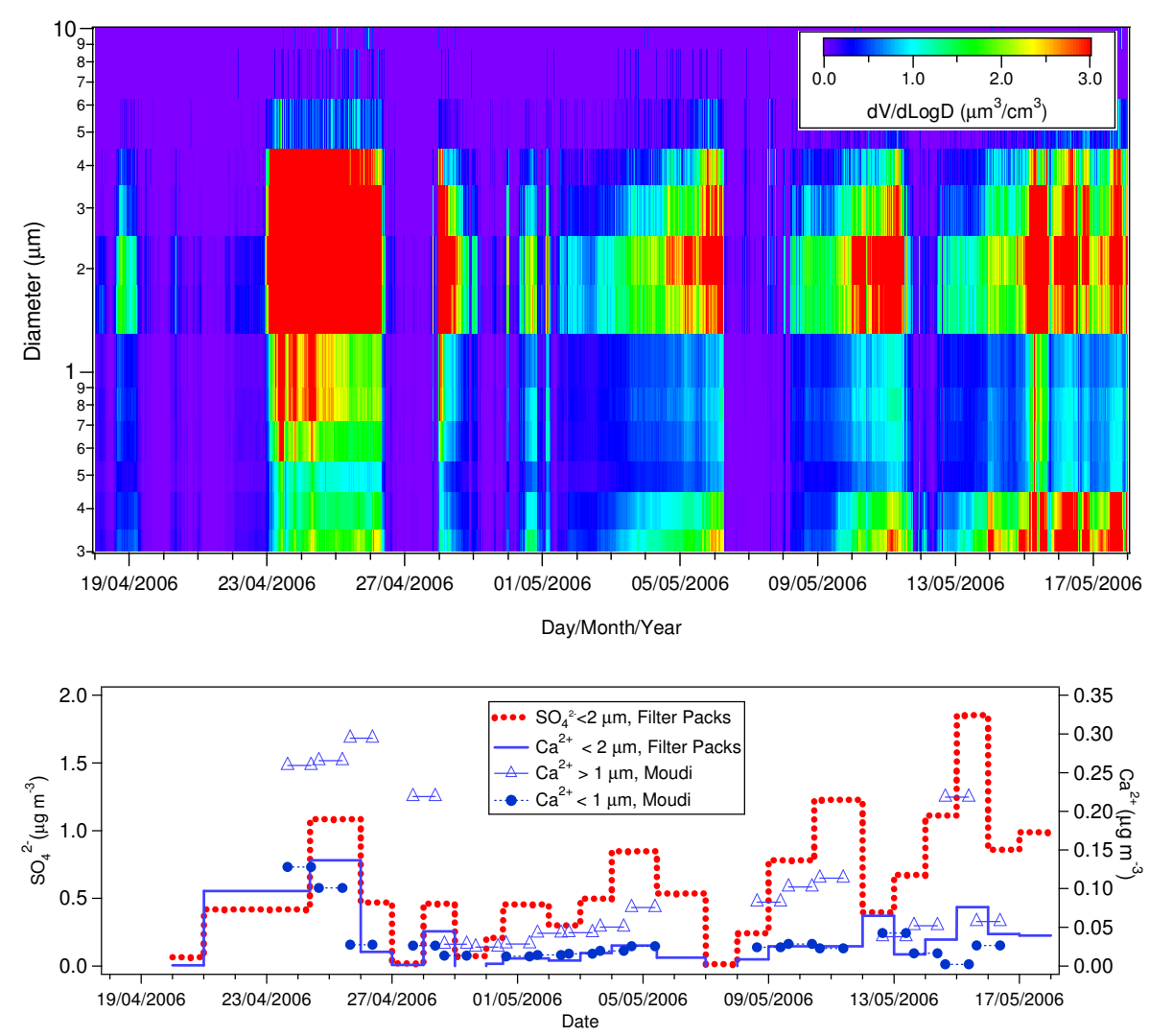

Fig. 2. (a) Two dimensional image plot of particle volume distributions from the Grimm optical particle counter at Whistler Peak from 18 April to 18 May 2006. (b) Time series of sulfate and calcium collected from filter packs $(<2.5$ microns $)$ and calcium collected from Moudi impactors ( $<1$ micron and $>1$ micron).

receiver. The received photons are separated into $532 \mathrm{~nm}$ (elastic) and $607 \mathrm{~nm}$ (1st Stokes nitrogen Raman) wavelength channels through the use of an interference-filter based polychromator and detected using photomultiplier tubes and fast counting electronics.

\section{Results}

\subsection{Dust events at Whistler}

Observations at Whistler Peak from 23 April to 17 May 2006 show at least five distinct episodes of increased coarse particle number concentrations (Fig. 2a, b). Calcium in the coarse particle samples collected at Whistler Peak using the MOUDI show significant enhancements during the 22-26 April period as well as on 15 May. Calcium is also higher on 4 and 8-10 May; no samples were collected on 5, 6, 7 or 11 May. The mass concentration of coarse particle calcium on 28 April was the second lowest measured during the period, and the increase in coarse particle number concentrations on 28 April is connected to the boundary layer based on the aircraft profiles from that day. The episodes of late April,
2-5, 9-10 and 15 May are consistent with observations of sand/dust storm events (SDS) in Northeast Asia (Zhou et al., 2008), Aeronet observations from Saturna Island (location in Fig. 1) and modeling results described by Zhao et al. (2007). Of these four episodes, the highest magnitude, both in terms of particle number and calcium mass, occurred from 2326 April at Whistler and was associated with material with modal particle diameter in the range of 2-4 $\mu \mathrm{m}$ (Fig. 2 and Leaitch et al., 2008). The second highest, again both in number and calcium mass, occurred from 15-16 May (Fig. 2). Both events were in broad agreement in terms of magnitude and timing with NAAPS forecasts for Cheeka Peak (available at http://www.nrlmry.navy.mil/aerosol/), an atmospheric chemistry monitoring site in the US just south of Vancouver Island. Based on the magnitude of the 23-26 April and 1516 May dust events at Whistler, and their connection with sulfate aerosol (Fig. 2b), these two events provide the focus of this study.

\subsection{Meteorology and Asian dust storms}

GEOS-Chem was used to estimate dust emissions and transport from Asia to North America. The top panel of Fig. 3 

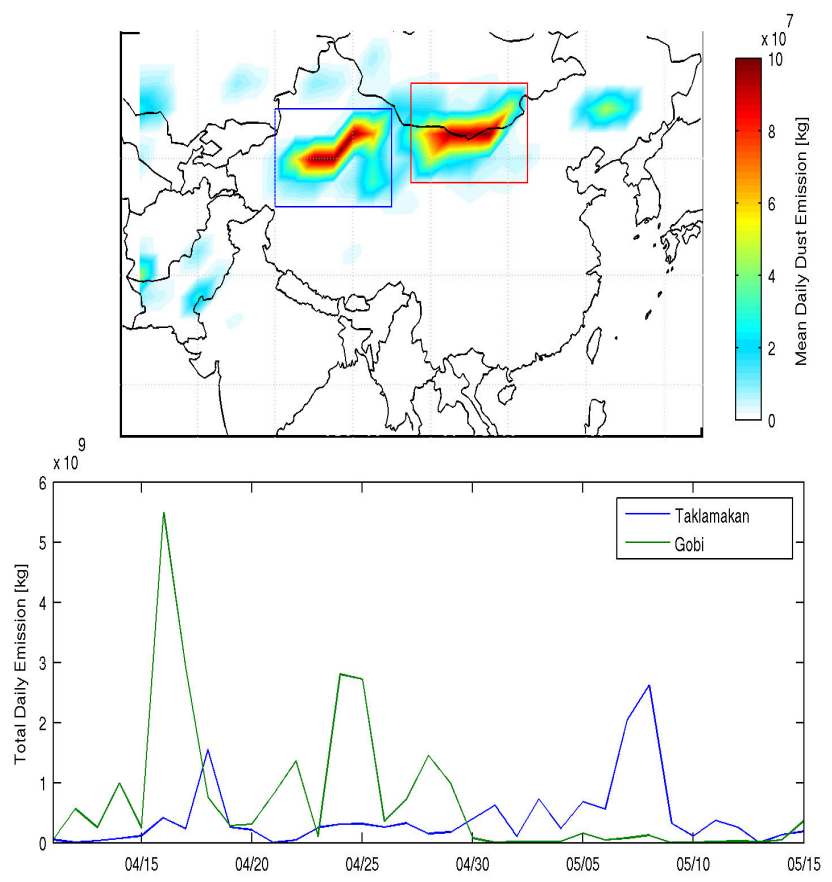

Fig. 3. Simulated dust emissions over East Asia during INTEX-B. The top panel shows average emissions for this period. The bottom panel shows temporal variation of total daily emissions within the regions outlined in the upper panel.

shows simulated daily mean dust emissions over China between 6 April and 19 May 2006. The bottom panel plots simulated total daily dust emissions within enhancement regions, as outlined within the blue and red boxes, and corresponding to the Taklamakan and Gobi deserts, respectively. Significant dust emissions are produced on 16 April, 24-25 April and 78 May. The Asian dust storms of 16 April and 7-8 May, are the likely origin for the dust events observed at Whistler Peak on 23-26 April and 15-16 May. Zhou et al. (2008), in an inventory of SDS activity in 2005 and 2006, also note severe SDS activity in the period 15-19 April 2006 in Mongolia that influenced regions including northern China, the Korean Peninsula and Japan. High emissions of dust evident in the period 24-25 April in Fig. 3, did not result in significant transport to the Canadian west coast due to inauspicious meteorology. In this case, trans-Pacific transport of crustal material was relatively weak with a zonal trajectory to the south of Whistler (NAAPS archive - available at http://www.nrlmry.navy.mil/aerosol/).

Figure 4 shows the simulated transport across the Pacific Ocean of dust aerosol generated from the 16 April and 8 May emission events. To concisely represent plume flow, Fig. 4 is generated by regularly sampling the simulated aerosol optical depth of dust at constant longitudinal spacing from the emission date until arrival at Whistler Peak. As in previously documented dust incursions (Husar et al., 2001; Jaffe et al., 2003; McKendry et al., 2007) both events involved direct transport across the Pacific in well-developed zonal flow. Both cases took approximately one week for transport and are consistent with the most probable trans-Pacific midtropospheric transit times of 6-8 days calculated by Holzer et al. (2005). Columnar flux patterns, shown as blue arrows on Fig. 4, suggest two distinct pathways taken during transport, with the April event arriving at Whistler Peak via a northerly route and the May event from the south. This may be an important factor contributing to differences in the chemical signatures of the two events (see below).

\subsection{Whistler observations: vertical profiles and lidar}

Vertical profiles of particle counts, and sulfate and organic aerosol concentrations derived from Cessna flights on 25 April and 15 May are shown in Fig. 5a-c. The 25 April fine particle aerosol profile (Fig. 5a) is marked by two distinct components. In the boundary-layer (BL), which extended to about $3 \mathrm{~km}$ based on the vertical distribution of sulfates, organics and particle number concentrations, the fine particles were composed of about $60 \%$ organic material, $30 \%$ sulfate, and much of the balance was made up by nitrate and ammonium. Above $3 \mathrm{~km}$, the fine particle aerosol was almost completely dominated by sulfate. Coarse particle chemistry during INTEX-B was measured only at Whistler Peak (Leaitch et al., 2008). The number concentrations of particles $>1 \mu \mathrm{m}$ (i.e. PCASP and OPC) were higher above $3 \mathrm{~km}$ and much lower in the boundary-layer, consistent with the transport of dust from Asia. The presence of a predominantly sulfate aerosol is also consistent with past observations (e.g. Brock et al., 2004) and other observations during INTEX-B (e.g. Peltier et al., 2008; Dunlea et al., 2008; van Donkelaar et al., 2008), and suggest that the aerosol was formed by the oxidation of $\mathrm{SO}_{2}$ during transport, in both cloud and the gas phase. The fine particles above $3 \mathrm{~km}$ were also larger than those in the boundary layer. This is evident in the PCASP size distributions (Leaitch et al., 2008) and from Fig. 7; the reduction in particle number concentrations from the BL to above $3 \mathrm{~km}$ is about a factor of four whereas the reduction in the fine particle mass is a factor of two or less. An increase in the size of the fine particles is an indication of a longer lived aerosol, which is consistent with trans-Pacific transport. Ozone is relatively high in the BL, and it increases from about $65 \mathrm{ppbv}$ at $3 \mathrm{~km}$ to about $70 \mathrm{ppbv}$ at $4.7 \mathrm{~km}$. It increases another $10 \mathrm{ppbv}$ in the plume between 4.7 and $5.2 \mathrm{~km}$, evidence that photochemical production of ozone accompanied the production of sulfate. The INTEX-B observations were interpreted with a global chemical transport model (GEOS-Chem) to estimate that Asian anthropogenic emissions during the period increased the mean profiles observed over Whistler for fine particle sulfate by $56 \%$ (van Donkelaar et al., 2008) and for ozone by $6-8 \mathrm{ppbV}$ (Walker et al., 2008).

As discussed by Sun et al. (2008), a predominantly sulfate plume impacted the Peak site on the morning of 15 May (Fig. 5b). The profile data show an increase in sulfate 


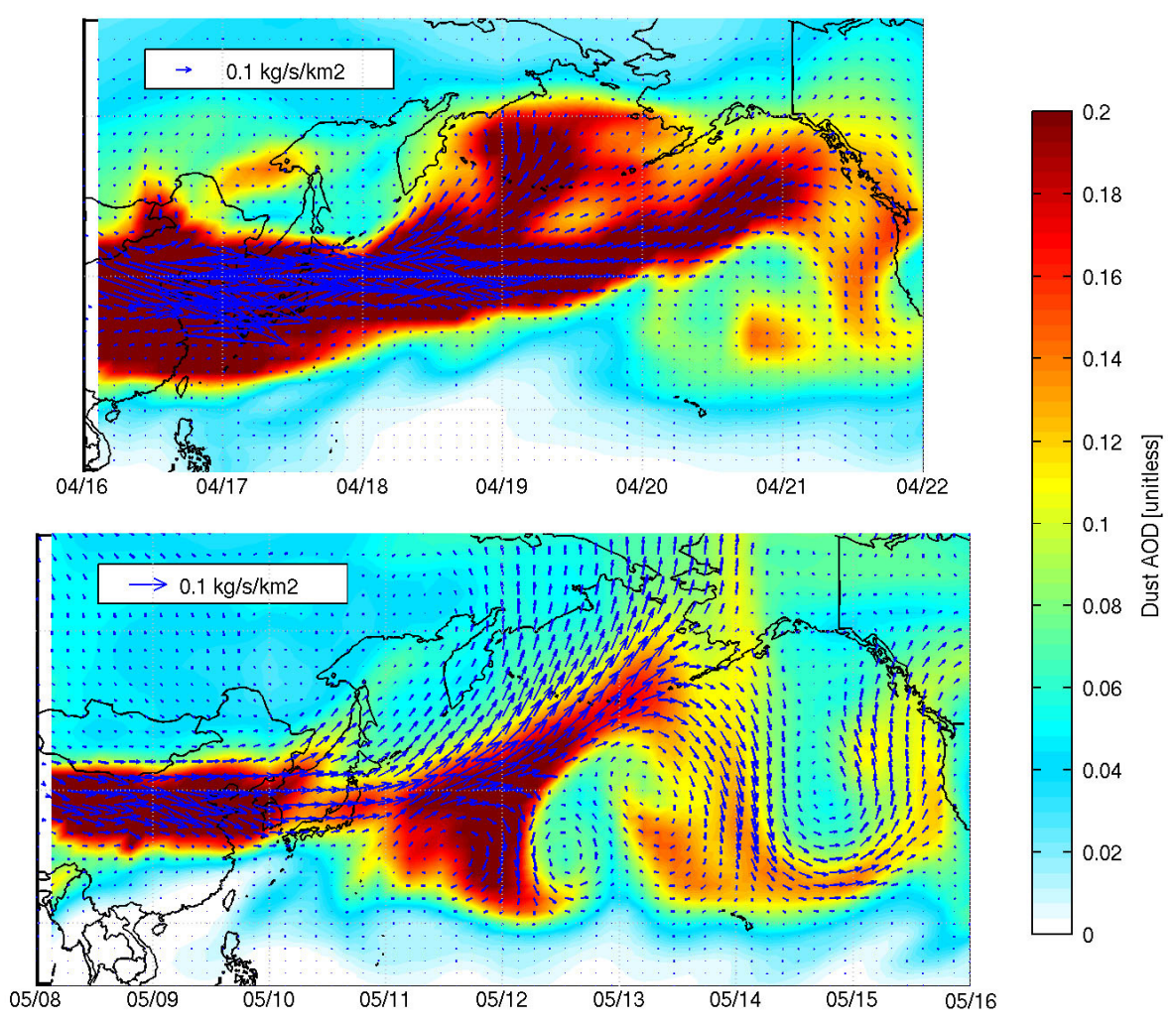

Fig. 4. Transport pathways of East Asian dust plumes. Both panels show the simulated dust component of aerosol optical depth sampled at the dates shown, approximately following plume flow between simulated emission and observation at Whistler Peak. Arrows denote columnar flux magnitude and direction.
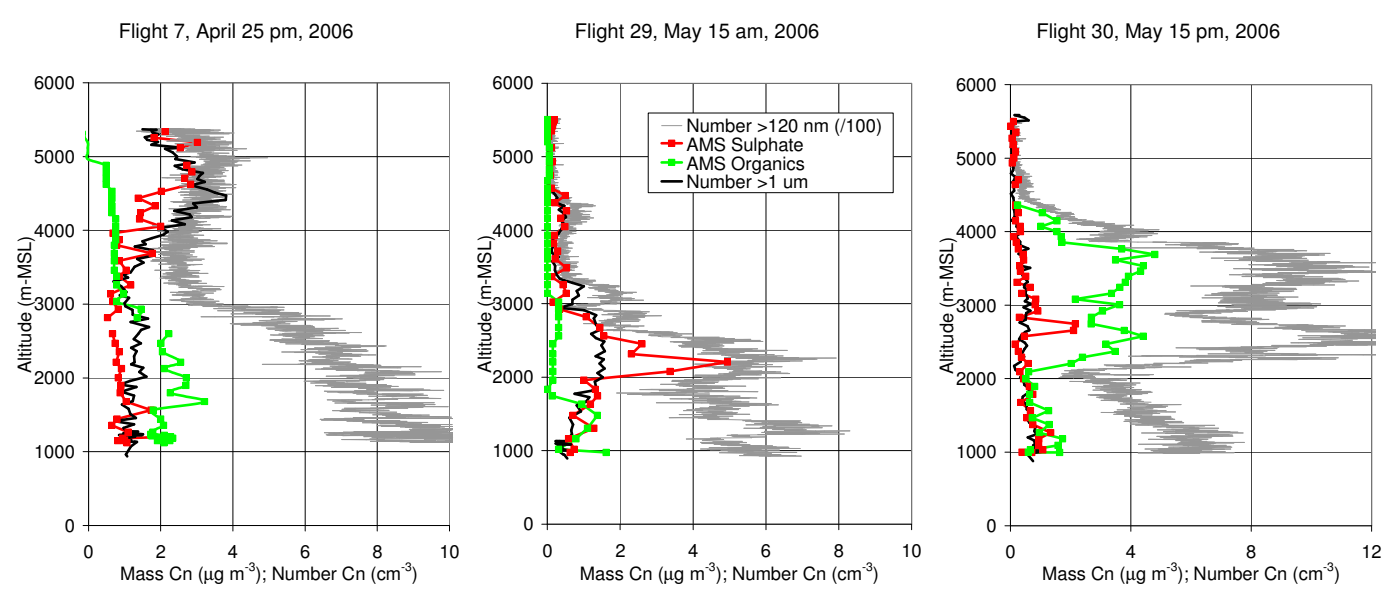

Fig. 5. Vertical profile data of sulfate and total organic fine particle mass concentrations (measured with a quadrapole AMS) and the number concentrations of aerosol particles larger than $120 \mathrm{~nm}$ diameter and larger than $1 \mu \mathrm{m}$ diameter. Note: the number concentrations of particles $>120 \mathrm{~nm}$ are divided by 100 .

between $2 \mathrm{~km}$ and $2.5 \mathrm{~km}$ at an elevation coincident with Whistler Peak. Accompanying this was a modest increase in $\mathrm{O}_{3}$ and a substantial increase in $\mathrm{CO}$ (Leaitch et al., 2008).

Lidar imagery from the morning of 15 May 2006 (Fig. 6) confirms the presence of an aerosol layer at approximately the elevation of the Peak station (2182 ma.s.l.) and is in agreement with the profile data at this time (Fig. b). The backscatter ratio shown in Fig. 6 is calculated by dividing the $532 \mathrm{~nm}$ (elastic) signal by the $607 \mathrm{~nm}$ (molecular) signal and normalizing to unity in a region of clear air. Aerosols are 


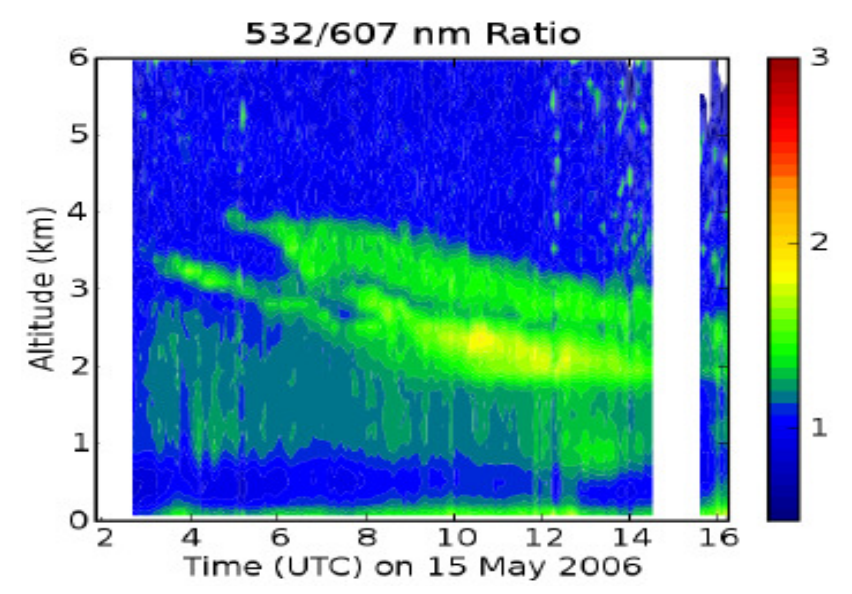

Fig. 6. Lidar imagery showing subsiding aerosol layer (Green) at Whistler on 15 May 2006.

identified by backscatter ratios greater than one. Note that the backscatter ratios presented are not corrected for the differential absorption between wavelengths due to aerosols and molecules. During the course of the 15 May event, lidar suggests that subsidence was a significant process bringing the sulfate-rich aerosol layer to mountain ridge level. The importance of subsidence in bringing dust layers in reach of the planetary boundary-layer over mountainous regions of western North America was identified by Hacker et al. (2001).

The situation changed dramatically by the afternoon of 15 May (Fig. 5c). While there was still a thin sulfate plume similar to that during the morning, the fine particle aerosol was clearly dominated by organics between $2 \mathrm{~km}$ up to about $4.4 \mathrm{~km}$. This abrupt change was also seen in the Peak data (Fig. 7, case 2). Trajectories for this time indicate subsiding air at the $2-5 \mathrm{~km}$ level, with origin from the south to south west over the previous one to two days. Longer range trajectories come from the mid-Pacific and northern China (Fig. 4). Sun et al. (2008) attribute the origin of the organic plume (Case 2, Fig. 7) to regional sources with likely contributions from the urbanized regions extending from southern Puget Sound to Georgia Strait (Seattle - BellinghamVancouver) with possible contributions from biomass burning that was evident along the California-Oregon border during the period (http://map.ngdc.noaa.gov/website/firedetects/ viewer.htm). In addition, given elevated tree emissions in the Whistler valley during the time period, biogenic secondary organic aerosol might also have contributed to the observed enhancement of organic aerosol mass.

\subsection{Comparison with previously documented cases}

In order to compare the dust events observed at Whistler during April-May 2006 with other documented dust events, IMPROVE data from the closest high altitude sites, with a sufficiently long record to encompass the Spring 1993 event,

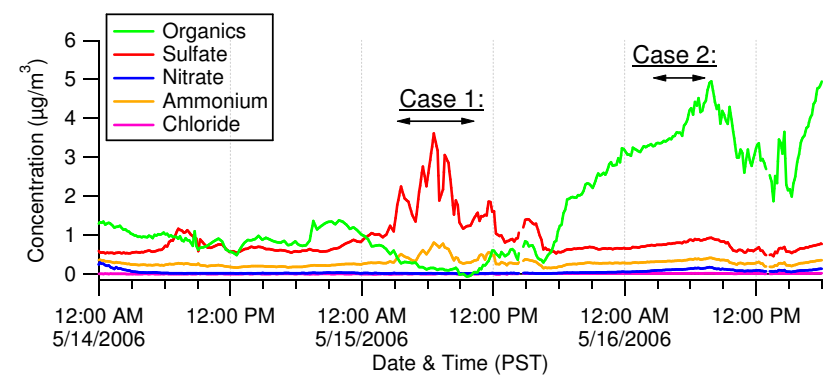

Fig. 7. Time series of the mass concentrations of total organic, sulfate, nitrate, ammonium and chloride in the fine particles as measured at Whistler Peak using a high-resolution time-offlight Aerosol Mass Spectrometer (W-TOF AMS). From Zhang et al. (2008).

were examined (Crater Lake, and Mt Hood, Oregon). Crater Lake is considered to be a pristine high altitude site that has been used in previous studies to examine trans-Pacific transport (Jaffe et al., 2005; Van Curen and Cahill, 2002; Zhao et al., 2008) and at approximately $2000 \mathrm{~m}$, it is of similar elevation to Whistler. Furthermore, $\mathrm{Ca}$ (an important element of the crustal dust signature along with $\mathrm{Si}, \mathrm{Fe}$ and $\mathrm{Al}$ ) and $\mathrm{SO}_{4}$ concentrations measured as part of fine aerosol IMPROVE monitoring are comparable to the Moudi sampler measurements made at Whistler.

Documented trans-Pacific dust events (including those of 2006) are listed in Table 1. At Whistler, Ca concentrations reached $0.14 \mu \mathrm{g} \mathrm{m}^{-3}$ on 24 April 2006 and were the highest since the start of record in 2002 (Fig. 2b). Concentrations during the May event were approximately half this value. Sulfate concentrations at Whistler for the 23-26 April and 15 May events reached 1.1 and $1.8 \mu \mathrm{g} \mathrm{m}^{-3}$ respectively (Fig. 2b). For comparison, the monthly geometric mean sulphate and calcium concentrations measured at Whistler for April and May from 2002-2006 range from $0.06 \mu \mathrm{g} \mathrm{m}^{-3}$ to $0.40 \mu \mathrm{g} \mathrm{m}^{-3}$ and $3 \mathrm{ng} \mathrm{m}^{-3}$ to $11 \mathrm{ng} \mathrm{m}^{-3}$ respectively (Macdonald et al., 2008b). When placed in the context of the longer term record from Crater Lake, these dust events pale in comparison to the large events of 1998 and 2001 when calcium concentrations were enhanced by factors of $30-40$ over mean background levels. However, the dust event of 2326 April 2006 observed at Whistler (and apparent at Crater Lake) appears to be one of the largest 4-5 events observed over the thirteen year period. The May 2006 dust event on the other hand, is of low magnitude with concentrations comparable to the Saharan dust episode observed in 2005 (McKendry et al., 2007).

For all events listed in Table 1, aerosol sulfate concentrations at Crater Lake were enhanced over annual mean background concentrations by factors in the range 2-5.6. This is smaller than the range of enhancements shown for crustal dust and likely reflects the relatively constant anthropogenic source strength for Asian $\mathrm{SO}_{2}$ compared to the 
Table 1. Crater lake Oregon and Whistler fine particle data. Comparison of documented trans-pacific dust events 1993-2006 with respect to relative importance of dust versus sulfate.

\begin{tabular}{|c|c|c|c|c|c|c|c|c|}
\hline \multirow[t]{2}{*}{$\begin{array}{l}\text { Date of arrival } \\
\text { on west coast }\end{array}$} & \multicolumn{3}{|c|}{$\begin{array}{l}\text { Crater lake (1996 m) } \\
\mu \mathrm{g} \mathrm{m}^{-3}\end{array}$} & \multicolumn{2}{|c|}{$\begin{array}{l}\text { Crater lake enhancement } \\
\text { factor over mean }\end{array}$} & \multicolumn{2}{|c|}{$\begin{array}{l}\text { Whistler (2100 m) } \\
\qquad \mu \mathrm{g} \mathrm{m}^{-3}\end{array}$} & \multirow[t]{2}{*}{ Related publications } \\
\hline & $\mathrm{Ca}$ & $\mathrm{SO}_{4}$ & $\begin{array}{l}\mathrm{SO}_{4} / \\
\mathrm{Ca} \text { ratio }\end{array}$ & $\mathrm{Ca}$ & $\mathrm{SO}_{4}$ & $\mathrm{Ca}$ & $\mathrm{SO}_{4}$ & \\
\hline 28 April 1993 & 0.12 & 1.74 & 14.5 & 6.2 & 5.6 & & & Jaffe et al. (2003) \\
\hline 29 April 1998 & 0.82 & 1.31 & 1.6 & 41.1 & 4.2 & & & $\begin{array}{l}\text { Husar et al. (2001), } \\
\text { Tratt et al. (2001) }\end{array}$ \\
\hline 16-24 March 1999 & 0.06 & 0.69 & 11.5 & 3.0 & 2.0 & & & NRL Case Study \\
\hline 16 April 2001 & $\overline{-}-40^{*}$ & $\begin{array}{l}1.18 \\
\left(0.95^{*}\right)\end{array}$ & $-\overline{2.4}$ & $\begin{array}{l}- \\
31^{*}\end{array}$ & $\begin{array}{l}3.8 \\
\left(2.4^{*}\right)\end{array}$ & & & $\begin{array}{l}\text { Jaffe et al. (2003), } \\
\text { Thulasiraman (2002), } \\
\text { Heald et al. (2006) }\end{array}$ \\
\hline 15 March 2005 & 0.10 & 0.68 & 6.8 & 5.1 & 2.2 & 0.05 & 0.7 & McKendry et al. (2007) \\
\hline 23-26 April 2006 & 0.20 & 0.93 & 4.7 & 9.9 & 3.0 & 0.14 & 1.1 & $\begin{array}{l}\text { this work, } \\
\text { van Donkelaar et al. (2008), } \\
\text { Macdonald et al. (2008), } \\
\text { Leaitch et al. (2008), } \\
\text { Zhang et al. (2008) }\end{array}$ \\
\hline 15 May 2006 & 0.05 & 0.81 & 16.2 & 2.6 & 2.6 & 0.08 & 1.8 & $\begin{array}{l}\text { this work, } \\
\text { van Donkelaar et al. (2008), } \\
\text { Macdonald et al. (2008), } \\
\text { Leaitch et al. (2008), } \\
\text { Zhang et al. (2008) }\end{array}$ \\
\hline
\end{tabular}

* Mt. Hood Oregon (1531 m) values

highly variable dust sources. Of particular note is the large magnitude 15 May 2006 sulfate aerosol event that produced concentrations at Whistler peak $\left(1.8 \mu \mathrm{g} \mathrm{m}^{-3}\right)$ exceeding the maximum sulfate aerosol associated with documented crustal dust events observed at Crater Lake $\left(1.74 \mu \mathrm{g} \mathrm{m}^{-3}\right.$ on 28 April 1993). Crater Lake sulfate concentrations on 15 May were relatively low compared to those at Whistler. This is likely a result of the northward trajectory of the aerosol along the Pacific coast during this event (Fig. 4) and suggests that the sulfate plume had less impact at Crater Lake in this case. Elevated sulfate concentrations in plumes above $2 \mathrm{~km}$ at Whistler were seen on several flights. In these plumes, the coarse particle concentrations were always found to increase relative to above and below, but the levels varied considerably. The highest coarse particle concentrations were in plumes sampled from 22-26 April 2006 and then on 15 May 2006; lower values were measured during 2-5 May 2006 (Leaitch et al., 2008). Certainly some significant elevated sulfate plumes were seen with relatively little or no dust.

Ratios of $\mathrm{SO}_{4}$ to $\mathrm{Ca}$ fine aerosol at Crater lake (Table 1) indicate some measure of the "mix" of aerosol for the different events, and together with enhancement factors, provide the basis for a somewhat subjective characterization of "events" with respect to the relative mix and magnitude of the sulfate vs mineral dust components On this basis it is possible to de- fine major dust events (29 April 1998, 16 April 2001, 23-26 April 2006) in which there was low to moderate sulfate enhancement. In other cases, the event incorporated dust but was a significant sulfate event (28 April 1993 at Crater Lake and 15 May 2006 at Whistler). Other cases (16-24 March 1999, and the Saharan dust event of 2005) are clearly of a more mixed nature with neither the sulfate or dust enhancements being particularly pronounced.

\section{Discussion and conclusions}

During INTEX B, two significant aerosol events incorporating Asian dust were observed at Whistler Peak and in nearby aircraft profiles over southwestern British Columbia. Both events showed enhancements of both sulfate aerosol and crustal material of Asian origin. However, the events were of quite different character and demonstrate the highly variable nature of such events. The April episode was a significant dust event (one of the largest 4-5 events over the previous 13 years) with considerable sulfate enhancement while the May episode was a weaker dust event also with significant fine particle sulfate enhancement at Whistler peak (but not at Crater Lake). The latter event was interesting in the sense that it was of short duration and was quickly followed by significant enhancement of organic material likely of regional 
origin. Although a thorough analysis of the significance of sulfate is outside the scope of this study, evidence was presented that East Asian enhancements of sulfate episodically degrade western Canadian surface air quality by as much as $1.5 \mu \mathrm{g} \mathrm{m}^{-3}$.

In terms of the meteorology of the two dust events observed during INTEX B, both were traceable to typical spring dust storms in China and shared the common pattern evident in previously documented cases (e.g., Husar et al., 2001; McKendry et al., 2005) of subsidence over western North America. Trajectories in the eastern Pacific were quite different in the two cases and were likely responsible for the differences in chemical "signature" of the two events. In contrast to the northerly approach to western North America in the April case, the May 2006 episode trajectory approached British Columbia from the south. As the trajectory became more southerly late on 15 May, the composition of the fine particle aerosol at Whistler Peak switched from high sulfate (likely of Asian origin) to high organic concentrations. It is believed that most of that fine particle organic mass was from regional sources over western North America and to the south of Whistler.

In summarizing the documented Asian dust events in Western North America, it is apparent that, in agreement with Heald et al. (2006), all dust events appear to show coincident enhancements of sulfate and crustal aerosol. However, events appear to vary across a wide continuum based on the magnitude of aerosol enhancements and their ratios. At one endpoint are events dominated by highly significant crustal enhancements (e.g. the well documented 1998 and 2001 "dust" events) while at the other end of the spectrum are events with some dust transport, but where sulfate enhancements are of very high magnitude (e.g. the 1993 event at Crater Lake and the 15 May 2006 event at Whistler). Other events lie somewhere between. It is likely that this variability is a function of:

1. the comparative strengths of the dust and anthropogenic $\mathrm{SO}_{2}$ sources

2. the transport pathway and in particular the extent to which dust is transported across industrial $\mathrm{SO}_{2}$ sources

3. meteorological and chemical processes. Of particular importance are the effects of precipitation, and the occurrence of favourable mid-tropospheric meteorological transport conditions (Holzer et al., 2005).

The coincident transport of sulfate and mineral aerosol evident in these events has potential implications for air quality compliance and visibility in western North America, and is likely evolving due to changes in land-use and anthropogenic emissions in Eurasian source regions. Furthermore, transport of sulfate and dust from Asia may have significant impacts on climate due to changes in particle size distributions and increased residence times of particles in the atmosphere.
Acknowledgements. Rob Buchanan provided professional and tireless piloting of the Cessna during the study. Tragically, Rob lost his life in the crash of the Cessna following the conclusion of the study. Mohammed Wasey, Armand Gaudenzi, Dave Halpin and John Deary provided technical and logistical support. This work was supported by the Natural Sciences and Engineering Research Council of Canada Special Research Opportunity Program and by Environment Canada. Special thanks to Juniper Buller, Anton Horvath, the Whistler Ski Patrol and Whistler Blackcomb for their support.

Edited by: J. Thornton

\section{References}

Brock, C. A., Hudson, P. K., Lovejoy, E. R., Sullivan, A., Nowak, J. B., Huey, L G., Cooper, O. R., Cziczo, D. J., de Gouw, J., Fehsenfeld, F. C., Holloway, J. S., Hübler, G., Lafleur, B. G., Murphy, D. M., Neuman, J. A., Nicks Jr., D. K., Orsini, D. A., Parrish, D. D., Ryerson, T. B., Tanner, D. J., Warneke, C., Weber, R. J., and Wilson, J. C.: Particle characteristics following cloud-modified transport from Asia to North America, J. Geophys. Res., 109, D23S26, doi:10.1029/2003JD004198, 2004.

Chin, Mian, Diehl, T., Ginoux, P., and Malm, W.: Intercontinental transport of pollution and dust aerosols: implications for regional air quality, Atmos. Chem. Phys., 7, 5501-5517, 2007, http://www.atmos-chem-phys.net/7/5501/2007/.

Cooper, O. R., Forster, C., Parrish, D., Trainer, M., Dunlea, E., Ryerson, T., Hübler, G., Fehsenfeld, F., Nicks, D., Holloway, J., de Gouw, J., Warneke, C., Roberts, J. M., Flocke, F., and Moody, J.: A case study of trans-Pacific warm conveyor belt transport: The influence of merging airstreams on trace gas import to North America, J. Geophys. Res., 109, D23S08, doi:10.1029/2003JD003624, 2004.

Duck, T. J., Firanski, B. J., Millet, D. B., Goldstein, A. H., Allan, J., Holzinger, R., Worsnop, D. R., White, A. B., Stohl, A., Dickinson, C. S., van Donkelaar, A.: Transport of forest fire emissions from Alaska and the Yukon Territory to Nova Scotia during summer 2004, J. Geophys. Res.-Atmos., 112, D10S44, doi:10.1029/2006JD007716, 2007.

Dunlea, E. J., DeCarlo, P. F., Aiken, A. C., Kimmel, J. R., Peltier, R. E., Weber, R. J., Tomlison, J., Collins, D. R., Shinozuka, Y., McNaughton, C. S., Howell, S. G., Clarke, A. D., Emmons, L. K., Apel, E. C., Pfister, G. G., van Donkelaar, A., Martin, R. V., Millet, D. B., Heald, C. L., and Jimenez, J. L.: Evolution of Asian aerosols during transpacific transport in INTEX-B, Atmos. Chem. Phys. Discuss., 8, 15 375-15 461, 2008, http://www.atmos-chem-phys-discuss.net/8/15375/2008/.

Fairlie, D. T., Jacob, D. J., and Park, R. J.: The impact of transpacific transport of mineral dust in the United States, Atmos. Environ., 41, 1251-1266, 2007.

Gong, S. L., Zhang, X. Y., Zhao, T. L., Zhang, X., McKendry, I. G., and Zhao, C. S.: A Simulated Climatology of Asian Dust Aerosol and its Trans-Pacific Transport 2. Interannual Variability and Climate Connections, J. Climate, 19, 104-122, 2006.

Hacker, J. P., McKendry, I. G., and Stull, R. B.: Modeled downward transport of Asian dust over Western North America during April 1998, J. Appl. Meteorol., 40, 1617-1628, 2001. 
Heald, C. L., Jacob, D. J., Park, R. J., Alexander, B., Fairlie, T. D., Yantosca, R. M., and Chu, D. A.,: Transpacific transport of Asian anthropogenic aerosols and its impact on surface air quality in the United States, J. Geophys. Res., 111, D14310, doi:10.1029/2005JD006847, 2006.

Holzer, M., McKendry, I. G., and Jaffe, D. A.: Springtime Trans-Pacific atmospheric transport from East Asia: A transit-time-PDF approach, J. Geophys. Res., 108(D22), 4708, doi:10.1029/2003JD003558, 2003.

Holzer, M., Hall, T. M., and Stull, R. B.: Seasonality and weatherdriven variability of trans - Pacific transport, J. Geophys. Res., 110, D23103, doi:10.1029/2005JD006261, 2005.

Husar, R. B., Tratt, D. M., Schichtel, B. A., Falke, S. R., et al.: The Asian Dust Events of April 1998, J. Geophys. Res., 106, $18317-$ 18333, 2001.

Jacob, D., Logan, J. A., and Murti, P. P.: Effect of Rising Asian Emissions on Surface Ozone in the United States, Geophys. Res. Lett., 26(14), 2175-2178, 1999.

Jaffe, D., McKendry, I., Anderson, T., and Price, H.: Six 'New' Episodes of Trans-Pacific Transport of Air Pollutants, Atmos. Environ., 37(3), 391-404, 2003.

Jaffe, D. A., Anderson, T., Covert, D., Kotchenruther, R., Trost, B., Danielson, J., Simpson, W., Berntsen, T., Karlsdottir, S., Blake, D., and Harris, J.: Carmichael G. and Uno I.: Transport of Asian Air Pollution to North America, Geophys. Res. Lett., 26, 711714, 1999

Jaffe, D., Snow, J., and Cooper, O.: The April 2001 Asian dust events: Transport and substantial impact on surface particulate matter concentrations across the United States, EOS Transactions, 84(46), 501-507, 2003.

Jaffe, D., Tamura, S., and Harris, J.: Seasonal cycle and composition of background fine particles along the west coast of the US, Atmos. Environ., 39, 297-306, 2005.

Jayne, J. T., Leard, D. C., Zhang, X., Davidovits, P., Smith, K. A., Kolb, C. E., and Worsnop, D. R.: Development of an aerosol mass spectrometer for size and composition analysis of submicron particles, Aerosol Sci. Tech., 33, 49-70, 2000.

Leaitch, W. R., Macdonald, A. M., Anlauf, K. G., Liu, P. S. K., Toom-Sauntry, D., Li, S.-M., Liggio, J., Hayden, K., Wasey, M. A., Russell, L. M., Takahama, S., Liu, S., van Donkelaar, A., Duck, T., Martin, R. V., Zhang, Q., Sun, Y., McKendry, I., and Cubison, M.: Evidence for Asian Dust Effects from Aerosol Plume Measurements during INTEX-B 2006 near Whistler, BC, Atmos. Chem. Phys. Discuss., accepted, 2008.

Li-Jones, X. and Prospero, J. M.: Variations in the size distribution of non-sea-salt sulfate aerosol in marine boundary layer at Barbados: Impact of African dust, J. Geophys. Res., 103(D13), 16073-16084, 1998.

Liu, P. S. K., Deng, R., Smith, K. A., Williams, L. R., Jayne, J. T., Canagaratna, M. R., Moore, K., Onasch, T. B., Worsnop, D. R., and Deshler, T.: Transmission Efficiency of an Aerodynamic Focusing Lens System: Comparison of Model Calculations and Laboratory Measurements for the Aerodyne Aerosol Mass Spectrometer, Aerosol Sci. Tech., 41, 721-733, 2007.

Macdonald, A. M., Anlauf, K. G., Leaitch, W. R., and Chan, E.: Interannual variability of ozone and carbon monoxide at the Whistler high elevation site, 2002-2006, in preparation, 2008.

Macdonald, A. M., Anlauf, K. G., and Leaitch, W. R.: Multi-year characterization of particles at a high elevation Pacific site, in preparation, 2008.

McKendry, I. G., Hacker, J. P., Stull, R., Sakiyama, S., Mignacca, D., and Reid, K.: Long range transport of Asian dust to the Lower Fraser Valley, British Columbia, Canada, J. Geophys. Res., 106(D16), 18 361-18370, 2001.

McKendry, I. G., Strawbridge, K., O’Neill, N., Macdonald, A. M., Liu, P., Jaegle, L., Jaffe, D., Fairlie, D., Anlauf, K., and Westphal, D.: A Case of Trans-Pacific Transport of Saharan Dust to Western North America, J. Geophys. Res., 112, D01103, doi:10.1029/2006JD007129, 2007.

Ohara, T., Akimoto, H., Kurokawa, J., Horii, N., Yamaji, K., Yan, X., and Hayasaka, T.: An Asian emission inventory of anthropogenic emission sources for the period 1980-2020, Atmos. Chem. Phys., 7, 4419-4444, 2007,

http://www.atmos-chem-phys.net/7/4419/2007/.

Peltier, R. E., Hecobian, A. H., Weber, R. J., Stohl, A., Atlas, E. L., Riemer, D. D., Blake, D. R., Apel, E., Campos, T., and Karl, T.: Investigating the sources and atmospheric processing of fine particles from Asia and the Northwestern United States measured during INTEX B, Atmos. Chem. Phys., 8, 1835-1853, 2008, http://www.atmos-chem-phys.net/8/1835/2008/.

Prospero, J. M., Ginoux, P., Torres, O., Nicholson, S., and Gill, T.: Environmental Characterization of Global Sources of Atmospheric Soil Dust Identified with the NIMBUS7 Total Ozone Mapping Spectrometer (TOMS) Absorbing Aerosol Product, Rev. Geophys., 40, 1, 1002, doi:10.1029/2000RG000095, 2002.

Stohl, A., Eckhardt, S., Forster, C., James, P., and Spichtinger, N.: On the pathways and timescales of intercontinental air pollution transport, J. Geophys. Res., 107(D23), 4684, doi:10.1029/2001JD001396, 2002.

Strapp, J. W., Leaitch, W. R., and Liu, P. S. K.: Hydrated and dried aerosol size distribution measurements from the Particle Measuring Systems FSSP-300 probe and the de-iced PCASP-100X probe, J. Atmos. Oceanic Technol., 9, 548-555, 1992.

Streets, D. G. and Waldhoff, S. T.: Present and future emissions of air pollutants in China: SO2, NOx, and CO, Atmos. Environ., 34, 363-374, 2000.

Sun, Y., Zhang, Q., MacDonald, A. M., Hayden, K., Li, S.-M., Liggio, J., Liu, P. S. K., Anlauf, K. G., Steffen, A., Leaitch, W. R., Cubison, M., Worsnop, D., van Donkelaar, A., and Martin, R. V.: Size-resolved aerosol chemistry on Whistler Mountain, Canada with a high-resolution aerosol mass spectrometer during INTEXB, Atmos. Chem. Phys. Discuss., accepted, 2008.

Thulasiraman, S., O’Neill, N. T., Royer, A., Holben, B. N., Westphal, D. L., and McArthur, L. J. B.: Sunphotometric observations of the 2001 Asian dust storm over Canada and the U.S., Geophys. Res. Lett. 29(8), 1255, doi:10.1029/2001GL014188, 2002.

Tratt, D. M., Frouin, R. J., and Westphal, D. L.: April 1998 Asian Dust event: a southern California perspective, J. Geophys. Res., 106, 18 371-18379, 2001.

VanCuren, R. A.: Asian aerosols in North America: Extracting the chemical composition and mass concentration of the Asian continental aerosol plume from long-term aerosol records in the western United States, J. Geophys. Res., 108(D20), 4623, doi:10.1029/2003JD003459, 2003

Van Curen, R. A. and Cahill, T. A.: Asian Aerosols in North America: Frequency and Concentration of fine dust, J. Geophys. Res., 107, 4804, doi:10.1029/2002JD002204, 2002.

van Donkelaar, A., Martin, R. V., Leaitch, W. R., Macdonald, A. M., 
Walker, T. W., Streets, D. G., Zhang, Q., Dunlea, E. J., Jimenez, J. L., Dibb, J. E., Huey, L. G., Weber, R., and Andreae, M. O.: Analysis of aircraft and satellite measurements from the Intercontinental Chemical Transport Experiment (INTEX-B) to quantify long-range transport of East Asian sulfur to Canada, Atmos. Chem. Phys., 8, 2999-3014, 2008,

http://www.atmos-chem-phys.net/8/2999/2008/.

Walker, T. W., Martin, R. V., van Donkelaar, A., Leaitch W. R., Macdonald, A. M., Anlauf, K., Cohen, R. C., Huey, G., Avery, M., Weinheimer, A., Flocke, F., Tarasick, D., Thompson, A., Streets, D. G., Ziemke, J., Bucsela, E., and Celarier, E.: TransPacific transport of reactive nitrogen and ozone to Canada during spring, Atmos. Chem. Phys. Discuss., in preparation, 2008.

Zhang, L., Jacob, D. J., Boersma, K. F., Jaffe, D. A., Olson, J. R., Bowman, K. W., Worden, J. R., Thompson, A. M., Avery, M. A., Cohen, R. C., Dibb, J. E., Flock, F. M., Fuelberg, H. E., Huey, L. G., McMillan, W. W., Singh, H. B., and Weinheimer, A. J.: Transpacific transport of ozone pollution and the effect of recent Asian emission increases on air quality in North America: an integrated analysis using satellite, aircraft, ozonesonde, and surface observations, Atmos. Chem. Phys., 8, 6117-6136, 2008, http://www.atmos-chem-phys.net/8/6117/2008/.
Zhao, T. L., Gong, S. L., Zhang, X. Y., McKendry, I. G., and Zhou, Z. J.: A Simulated Climatology of Asian Dust Aerosol and its Trans-Pacific Transport 1. Mean climate and validation, J. Climate, 19(1), 88-103, 2006.

Zhao, T. L., Gong, S. L., Zhang, X. Y., and Jaffe, D. A.: Asian dust storm influence on North American ambient PM levels: observational evidence and controlling factors, Atmos. Chem. Phys., 8, 2717-2728, 2008, http://www.atmos-chem-phys.net/8/2717/2008/.

Zhou, C. H., Gong, S. L., Zhang, X. Y., Wang, Y. Q., Niu, T., Liu, H. L., Zhao, T. L., Yang, Y. Q., and Hou, Q.: Development and evaluation of an operational SDS forecasting system for East Asia: CUACE/Dust, Atmos. Chem. Phys., 8, 787-798, 2008, http://www.atmos-chem-phys.net/8/787/2008/. 